\author{
Majid Farahian \\ Assistant Professor of Applied linguistics \\ Department of ELT, Kermanshah Branch, Islamic Azad University, Kermanshah, Iran \\ ORCID ID 0000-0002-5367-5138 \\ farahian@iauksh.ac.ir
}

\title{
Farshad Parhamnia
}

Assistant Professor of Knowledge and Information Science

Department of Knowledge and Information Science, Kermanshah Branch, Islamic Azad University,

Kermanshah, Iran

ORCID ID 0000-0003-1509-3329

fparhamnia@yahoo.com

Milad Sheikhbanooie

MA student of Applied Linguistics

Department of ELT, Kermanshah Branch, Islamic Azad University, Kermanshah, Iran

ORCID ID 0000-0003-4971-6440

miladsheikhbanooe@gmail.com

\section{WEB QUESTING IN TEFL COURSES: WHAT FACTORS DETER THE STUDENTS’ INFORMATION-SEEKING BEHAVIOR?}

\begin{abstract}
The survival and the continuity of an organization's operations depend upon the use of information. As such, investigating the Webquesting behavior of university students in general and TEFL (Teaching English as a foreign language) students in particular during the Covid 19 seems essential. Since information-seeking behavior can be influenced by various factors we aimed to explore the attitude of TEFL students towards webquesting. In the next phase of the study, we sought the barriers to TEFL students' Webquesting behaviour. Accordingly, the present research employed both qualitative and quantitative approaches. The statistical population consisted of 128 TEFL students and the sampling method was purposeful. The findings of this study revealed that the students were not satisfied with their webquesting and that there were two major obstacles in their webquesting, namely, learners' constraints and teachers' constraints. The inhibitors included lack of familiarity with Internet sources, poor information seeking skills, lack of interest in some topics, lack of skills in using the Internet, poor English proficiency, teachers' lack of CALL (computer assisted language learning) preparation, lack of help from the side of teachers, teachers' lack of attention to non-textbook resources, and students' lack of motivation and time. Findings have implications for TEFL teachers, since, based on the qualitative data, the most important source of information for students is textbooks and the most important goal of searching for information is for doing homework. The importance of textbooks for students is the result of the pivotal role given to the text books by teachers and the final exams. Perhaps students' lack of interest in webquesting is partly due to such an undue emphasis. On the other hand, students' lack of interest in Webquesting was also due to the lack of attention and encouragement from the side of teachers to use the Internet resources.
\end{abstract}

Keywords: WebQuesting; barriers to information-seeking behaviour; TEFL students.

\section{INTRODUCTION}

The problem statement. Information and access to it are essential for economic and social development. Information is an inseparable component of human life and is so crucial in today's world that it can be considered the main factor in the growth and development of a society. The survival and the continuity of an organization's operations depend upon the use of information, and universities are no exception; however, since information is widely available around the world, access to information and ways of using it in universities to promote knowledge production and research require special consideration in terms of the information-seeking behavior of individuals. In addition, information-seeking behavior is a 
reflection of users' information needs, so it is very important to identify and have a correct understanding of this behavior. Furthermore, information-seeking behavior in TEFL courses plays a significant role in the students' academic success, especially during the COVID-19 epidemic.

Analysis of recent studies and publications. Various studies have been conducted on information-seeking behavior of university students in Iran. For example, study [1] examined the information-seeking behavior of Islamic Azad University students. According to the results of this study, there was no significant difference between the behavior of humanities, medical sciences, basic sciences, engineering and agriculture students, and students used both formal and informal methods to find information. Moreover, the study reported that participants used more print than non-print sources. Riahi studied the information-seeking behavior of nursing students and stated that the most important source of information for this group of students was textbooks and journals. In addition, as reported, the most important goal of the study population was homework [2]. Shariatmadari addressed the barriers to counseling students' information-seeking behavior and reported that the most important barriers for these students were lack of necessary facilities, their inability to use non-Persian sources and lack of time [3]. In study [4], students' lack of familiarity with the databases related to the field of study and the limitations of the Internet were investigated. Another study found that lack of time is the most important barrier to information for medical students [5]. Research [6] studied academic webquesting among undergraduate students. Based on the findings, the information seeking in order to do homework was ranked first and the exchange of information and homework with teachers was ranked last. Moreover, study [7] reported that educational level is one of the effective factors in information-seeking behavior. Radad also explored the information-seeking behavior of doctoral graduate students when using the web. According to the findings, students know the impact of the web network on their information-seeking activities, but found limitations in using it [8].

The research goal. Since information-seeking behavior can be influenced by various factors, we explored the attitude of TEFL students towards webquesting. In addition, in the next phase of the study, we sought the barriers in TEFL students' webquesting.

\section{THE THEORETICAL BACKGROUNDS}

Over the past three decades, the importance of information needs among countries has doubled, and information-seeking behavior has become particularly important and has been studied as a scientific discipline. Information-seeking behavior includes a set of activities that a person performs to meet his/her information needs after identifying the existence of doubt in him/herself. This behavior includes information search objectives, search method, search tool, the type of information sought and the factors affecting it [9]. Regarding information behaviors, Wilson distinguishes four types of behaviors, including information behavior, information-questing behavior, information-seeking behavior, and information-use behavior. He defines information-questing behavior as the purposeful search for information that an individual engages in to meet specific information needs in interacting with information systems or computer systems. He points out that information behavior involves the whole human behavior towards information sources and channels [10]. Marchionne defines information-seeking behavior as "a process in which human beings purposefully seek to change the knowledge position" [11]. In another definition in the discussion of information seeking, motivational factors, behavioral considerations, intellectual development and personality types are introduced as influential factors [12]. However, one of the most important factors in the information-questing behavior of the person who searches for information is his/her specific characteristics that affect the search strategies and general 
information-seeking behavior. These characteristics include demographic and psychological characteristics [13]. Besides, one of the important discussions of information-seeking behavior is about this behavior being influenced by cognitive aspects and individual behavior. For instance, Ingwersen believes that the information-seeking process is associated with cognitive factors, such as thinking, cognition, memory, recognition, learning, and problemsolving [14]. Although information seeking has been the subject of much research, webquesting has become increasingly crucial in the Covid 19 era, and this has multiplied the importance of the role of technology in education.

In recent decades much attention has been paid to the role of technology in education and technological tools like computers, compact discs and digital cameras have had a widespread use. It has been argued that technologies can be used in order to improve the teaching and learning process and to overcome the training challenges [15]. Technology has also found its place in teaching English as a foreign language (EFL), and CALL (computer assisted language learning) has drawn lots of attention. Technological tools such as software applications, computers, and the Internet have enabled teachers to teach vocabulary, grammar, and pronunciation, and at the same time have provided a suitable and interactive learning environment for learners. In addition, students can practice four language skills, engage in an interactive process of learning. In addition, digital technologies have offered both synchronous and asynchronous communication, in such a way that "there is a wealth of opportunities for preservice teachers to investigate topics and issues within the global classroom, with peers and experts" [16, p.1].

WebQuests as inquiry-oriented activities like other technological tools have been used by teachers to assist them with the teaching process. As March [17, p.2] explains:

A WebQuest is a scaffolded learning structure that uses links to essential resources on the World Wide Web and an authentic task to motivate students' investigation of a central, open-ended question, development of individual expertise and participation in a final group process that attempts to transform newly acquired information into a more sophisticated understanding. The best WebQuests do this in a way that inspires students to see richer thematic relationships, facilitate a contribution to the real world of learning and reflect on their own metacognitive processes.

A typical WebQuest task contains six stages, namely, (a) introduction; (b) task; (c) information sources; (d) description of process; (e) performance evaluation; and (f) conclusion [23, p.296]. A WebQuest that is designed on the basis of a student-centered and inquiry-based approach, is generally conducted based on an interesting scenario which necessitates students' critical thinking in order to examine "the problems, propose hypotheses, search for information with the web links provided by the instructor, analyze and synthesize the information using guided questions, and present solutions to the problems" [18, p.296].

With the spread of the COVID-19 pandemic in the world education activities suspended temporarily, then in a short time full-online classes named emergency e-learning, which refers to a rapid change from face-to-face education to virtual education [19], were introduced. Based on the researchers' experience it seems that although the virtual courses did not perform as an ideal condition, the online courses were a suitable remedy for the unwanted situation. In this way, Iranian universities built accounts for teachers, students, and so on often in a Learning Management System (LMS) as a platform in e-learning.

\subsection{Research questions}

1. What is the attitude of TEFL students towards Webquesting? 
2. What are barriers to TEFL students' Webquesting behaviour?

\section{RESEARCH METHODS}

\subsection{Participants}

Eighty-seven (65 females and 22 males) TEFL students were selected based on convenience sampling from a University in the west of Iran. The participants were undergraduate students who were majoring in TEFL, with the age ranging from 18 to 32.

\subsection{Instruments}

\subsubsection{A Web Quest-based information-seeking behavior scale}

A scale developed by Zheng et al [18] was adopted for the purpose of the study. The newly developed scale involved 20 items with a 5-point Likert scale ranging from strongly disagree to strongly agree (strongly disagree $=1$, strongly agree $=5$ ). (Appendix). As reported by Zheng et al [18] the theoretical construct of the questionnaire was constructed based on critical thinking, knowledge application, social skills and scaffolded learning.

To construct the questionnaire, we investigated both the content and construct validity of the scale. In doing this, we followed the following steps:

As the first step, we asked three experts to pass their judgments as to the clarity of items. As a result, some items were revised and three were removed. Then, we employed a principal component analysis to validate the questionnaire. Based on obtained results of the correlation matrix 4 items were removed. At the second factor analysis, the obtained KMO (Kaiser-MeyerOklin) was 0.71 , which indicated the suitability of the data. Bartlett's Test of Sphericity also showed statistical significance $(\chi 2(511)=6314.42, p=0.000<0.05)$. Based on a principal component factor analysis with Varimax rotation all remaining $\mathrm{x}$ items had acceptable loadings. Each item was followed by a 5-point Likert scale including "not at all", 2 "to a small scale", 3 "to some extent", 4 "to a moderate extent, and 5 "to a great extent. The reliability of the scale was ensured, since the estimated Cronbach $\alpha$ was found to be adequate (.81).

\subsubsection{The Semi-Structured Interview}

A semi-structured interview with 24 volunteer TEFL students was carried out. The first two questions on the semi-structured interview inquired how the students got acquainted with webquesting, whether or not they utilized webquesting in their classes as homework. The next two questions enquired about the problems and barriers to Webquesting in the previous and current semesters. As to the process of the interview, first, we made sure that the participants were well-motivated to participate in the interview. Next, two experts in the field of TEFL were invited to review the interview questions. We conducted the interviews in the first language of the interviewees (Persian) in order to give them the opportunity to express their ideas freely. After we received the consent of the participants, we recorded and transcribed the responses. It is noteworthy that we translated each interview into English. Finally, the data was transcribed and codified. Each interview lasted for 40 minutes. 


\subsection{Data Analysis}

To analyze the data, first the descriptive analysis of the questionnaire was performed. In the next phase, content analysis based on the interview transcripts was conducted. As Mayring [20] puts it, while doing content analysis, the researcher summarizes and reports data in a way that "the essential contents are preserved but a short, manageable text is produced" [20, p. 268].

\section{THE RESULTS AND DISCUSSION}

\subsection{THE RESULTS}

\subsubsection{Quantitative phase}

The demographic characteristics of the respondents presented in Table 1 show that females and males constituted 65 (74.7\%), and $22(25.3 \%)$ of the participants, respectively. In terms of Internet usage, it was shown that $6(6.9 \%)$ use the Internet very little, $24(27.6 \%)$ little, $29(33.3 \%)$ moderatly, $20(23 \%)$ much, and $8(8.9 \%)$ very much. Also, in terms of information search skills on the Internet, it was found that $10(11.5 \%)$ have very basic skills, $28(32.2 \%)$ basic, $31(35.6 \%)$ average, $12(13.8 \%)$ good, and $6(6.9 \%)$ have very good skills..

\section{The summary of the respondents' demographic, Internet use, and skill information retrieval statistics}

\begin{tabular}{cccc}
\hline Category & Profile & Frequency & Percentage \\
\hline \multirow{2}{*}{ Gender } & Females & 65 & 74.7 \\
& Males & 22 & 25.3 \\
\cline { 2 - 4 } & very little & 6 & 6.9 \\
Internet & little & 24 & 27.6 \\
usage rate & medium & 29 & 33.3 \\
& much & 20 & 23 \\
& very much & 8 & 8.9 \\
\cline { 2 - 4 } Skills in & very basic & 10 & 11.5 \\
information & basic & 28 & 32.2 \\
retrieval & medium & 31 & 35.6 \\
& good & 12 & 13.8 \\
& very good & 6 & 6.9 \\
\hline
\end{tabular}

In answer to the first question, namely, what is the attitude of TEFL students towards webquesting, descriptive statistics (mean and standard deviation) were used, which are shown in Tables 2-3.

Table 2

\section{Descriptive statistics of students' responses}

\begin{tabular}{|c|l|c|c|}
\hline NO. & \multicolumn{1}{|c|}{ Responses } & Mean & Std. Deviation \\
\hline 1 & We are often given home assignments based on WebQuest. & 2.74 & .838 \\
\hline 2 & $\begin{array}{l}\text { We have been given instructions by the teacher how to do } \\
\text { WebQuest. }\end{array}$ & 2.94 & .826 \\
\hline 3 & I know how to use the internet to do WebQuest. & 2.57 & .963 \\
\hline
\end{tabular}




\begin{tabular}{|c|c|c|c|}
\hline 4 & $\begin{array}{l}\text { In the WebQuest learning during the course, I have learned to } \\
\text { examine a problem from various aspects. }\end{array}$ & 2.45 & .789 \\
\hline 5 & $\begin{array}{l}\text { Based on the WebQuest learning, I can develop the ability to } \\
\text { challenge my classmates' or the teacher's point of view. }\end{array}$ & 2.67 & .842 \\
\hline 6 & $\begin{array}{l}\text { The WebQuest helps me arrive at a conclusion by assembling the } \\
\text { various evidences through reasoning. }\end{array}$ & 3.04 & .963 \\
\hline 7 & $\begin{array}{l}\text { By using WebQuest, I have learned to propose a solution with more } \\
\text { than one approach. }\end{array}$ & 2.47 & .846 \\
\hline 8 & $\begin{array}{l}\text { By using WebQuest, I have learnt to solve the problem with more } \\
\text { than one solution. }\end{array}$ & 2.52 & .728 \\
\hline 9 & $\begin{array}{l}\text { The WebQuests has enabled me to effectively use the information } \\
\text { to solve problems. }\end{array}$ & 3.12 & .925 \\
\hline 10 & $\begin{array}{l}\text { In the WebQuest learning environment, the knowledge gained from } \\
\text { one problem solving situation can be transferred to another } \\
\text { situation. }\end{array}$ & 2.51 & .567 \\
\hline 11 & $\begin{array}{l}\text { In the WebQuest learning environment, I am able to pull knowledge } \\
\text { from different fields to solve problems. }\end{array}$ & 2.57 & .816 \\
\hline 12 & $\begin{array}{l}\text { The structured nature of the WebQuest facilitates retrieval of prior } \\
\text { knowledge to new learning. }\end{array}$ & 2.55 & .973 \\
\hline 13 & $\begin{array}{l}\text { Collaboration among learners in WebQuests learning promotes } \\
\text { positive interdependence. }\end{array}$ & 2.65 & .661 \\
\hline 14 & WebQuests learning promotes accountability among learners. & 2.66 & .772 \\
\hline 15 & $\begin{array}{l}\text { Learners gain a better understanding of each other's points of view } \\
\text { in a WebQuest learning environment. }\end{array}$ & 2.70 & .779 \\
\hline 16 & The WebQuest promotes interaction among learners. & 2.80 & .524 \\
\hline 17 & $\begin{array}{l}\text { Learners develop better interpersonal and small group skills in a } \\
\text { WebQuest learning environment. }\end{array}$ & 3.03 & 1.135 \\
\hline 18 & $\begin{array}{l}\text { Scaffolding in WebQuest learning facilitates the understanding of } \\
\text { the subject content. }\end{array}$ & 2.96 & 1.061 \\
\hline 19 & $\begin{array}{l}\text { As homeworks, we are given some assignments to do based on The } \\
\text { WebQuests.. }\end{array}$ & 2.50 & .502 \\
\hline 20 & $\begin{array}{l}\text { In a WebQuest learning environment, scaffolding enables learners } \\
\text { to connect between their learning activities and goals. }\end{array}$ & 2.62 & .575 \\
\hline
\end{tabular}

As it can be seen, all means except 6, 9 and 17 are under the expected value (3).

Table 3

\section{One-Sample Test}

\begin{tabular}{|c|c|c|c|c|c|c|c|c|}
\hline \multirow[b]{4}{*}{$\begin{array}{l}\text { TEFL students towards } \\
\text { Webquesting }\end{array}$} & \multicolumn{8}{|c|}{ Test Value $=3$} \\
\hline & \multirow[b]{2}{*}{ Mean } & \multirow{2}{*}{$\begin{array}{c}\text { Std. } \\
\text { Deviation } \\
\end{array}$} & \multirow[b]{2}{*}{$\mathrm{t}$} & \multirow[b]{2}{*}{$\mathrm{df}$} & \multirow[b]{2}{*}{ Sig. (2-tailed) } & \multirow{2}{*}{$\begin{array}{c}\text { Mean } \\
\text { Difference } \\
\end{array}$} & \multicolumn{2}{|c|}{$\begin{array}{l}\text { 95\% Confidence Interval } \\
\text { of the Difference }\end{array}$} \\
\hline & & & & & & & Lower & Upper \\
\hline & 2.74 & .29442 & -8.011 & 86 & .000 & -.25287 & -.3156 & -.1901 \\
\hline
\end{tabular}

Based on Table 3, mean, and standard deviation BRPQ score $(2.74 \pm .294)$ was lower than the hypothetical mean (3). Thus, the difference between the BRPQ mean and the expected value (3) was significant.

\subsubsection{Qualitative phase}

After the quantitative phase, we conducted the qualitative phase, since qualitative follow-up investigations shed more light on the quantitative study [21]. 21 TEFL students took part voluntarily in the interview. 


\subsubsection{Data collection procedure}

As the first step, the questionnaire that was used to collect quantitative data was developed. The questionnaire was distributed among 115 TEFL undergraduate students. Because of Covid 19 lockdown we did not have direct access to all students, therefore Google Forms were used to gather the data. Of 115 questionnaires, 28 were disregarded, since they were haphazardly completed. It took about a month to collect the data. Finally, to ensure the validity and reliability of the scale an EFA was run using SPSS 21, followed by employing Cronbach alpha.

Semi-structured interviews were carried out to investigate TEFL students' perspectives of Web Quest-based information-seeking behavior scale. All the TEFL students were interviewed once, and the interviews were audio recorded. The interview included 4 openended questions on the impediments to information-seeking behaviour. During the study the students were told that their participation would remain confidential. The survey was carried out between January 2021 and March 2011. The major themes extracted are as follows:

\section{Not being familiar with Internet sources}

Information and communication technology is considered as one of the influential components in information-seeking behavior. Researchers and experts place special emphasis on knowledge and awareness of information resources, especially the Internet and Web resources and their proper use. Therefore, it is necessary to introduce these resources to students and help them identify these sources. In the present study, the interviewees referred to such an important point and lack of attention to various Internet resources. In this regard, one of the interviewees stated,

"Students have little information about the existence of Internet resources. We have never been told what they are and never searched for one".

\section{Poor information-seeking skills}

One of the most important factors in information retrieval is information-seeking skills. To obtain the desired information, you need to have such skills. In this regard, the interviewees explained that an obstacle to information seeking was their lack of informationseeking skills in English language courses. In this regard, one of the interviewees stated,

"Even if teachers introduce some Internet sources, we do not have sufficient skills to find suitable English language resources".

\section{Lack of interest in some topics}

In interviews with the students, it was found that some students are not interested in the topic they are going to search on the Internet and do it out of compulsion. One of the students stated in this regard:

"When I'm not interested in the subject, I like to finish the search faster. That's why I search quickly and without much attention."

\section{Lack of skills in using the Internet}

In today's world, mastering the skills of using information resources, especially the Internet, is a necessity for students. Students should be able to use online resources to find answers to their questions. In the present study, it was pointed out that one of the important factors in the lack of access to information required by students in English language courses was the lack of skills in using the Internet. In this regard, one of the interviewees states:

"Although they have sufficient skills in using a variety of social networks or mobile technologies, many students do not have sufficient skills in using the Internet to be able to search for the information they need for English language courses." 
Surprisingly, some students cited lack of familiarity with web browsing as one of the problems. Others were superficially familiar with the Internet environment in such a way that they did not know the difference between a blog environment and a scientific journal environment, although they were very familiar with social networks.

\section{Poor English proficiency}

Weakness in students' English is another barrier to finding information. In this regard, one of the interviewees stated, "The main weakness of English language courses is that most students, especially lower semester students, are not very good at reading English".

\section{Teachers' lack of CALL preparation}

Some students reported that their teachers were not familiar with the use of technology in the courses. As they said during the courses teachers did not make use of interactive features of the applications and kept lecturing during the whole class time. A student said, "I know that the teacher does not know how to use the device, she is often at a loss about the simplest matters".

\section{Lack of help from the side of teachers}

Teachers can introduce students to different sources in their course, and both at the beginning of the semester and during the semester regularly ask students to obtain information from these sources. In this regard, one of the issues mentioned by the interviewees was the lack of guidance from teachers on different sources. One of the interviewees said: "Most teachers did not provide this information. Why is that ... I think because they do not consider it necessary."

\section{Teachers' lack of attention to non-textbook resources}

In traditional teaching models, most learners consider the teacher and the textbook as the only source, and sometimes, given that they are accustomed to this method of teaching, they do not see the necessity to change their behavior [22]. One of the factors influencing the main obstacles in information-seeking behavior in academic language courses, especially TEFL courses, is the teachers' mere emphasis on book resources in higher education. At the beginning of the semester, the teacher just introduces a textbook and bases his/her evaluation on the same book. As one interviewee puts it:

"The point is that, in our society, most people equate lessons with books, and it makes no sense to use different sources like the ones found on the Internet. Well, this way of thinking makes both students and teachers know a lesson equal to the book ". Or another person stated:

"It was not only related to the university. In school, they put more emphasis on books than non-book sources. As such, such an attitude goes back to schools".

Another interviewee stated: "For a variety of reasons, teachers rely solely on books in the classroom. It seems that there is nothing but books to teach.".

The exceptional reliance on textbooks has become commonplace among TEFL students. [23] This will leave very large sources of information unused.

\section{Students' lack of motivation}

The process of motivation refers to the complex forces, drives, needs, stressful situations, or other mechanisms that initiate and perpetuate an individual's pursuit of his or her goals [24]. In the same vein, Bijani et al state that motivation is an inner state that energizes, activates, moves human behavior and leads to certain goals [25]. Therefore, one of the factors 
that can be the driving force to prevent information-seeking behavior is the poor motivation of students. In this regard, one of the interviewees stated:

"Among all the cases that may be effective, sometimes the student himself is an obstacle to his progress. For example, he has no motivation to search and does not have the patience to get to know other sources".

\section{Students' Lack of time}

In today's busy world, people take on several different tasks over a period of time. It is likely that students who have livelihood problems or are married spend less time on resources other than textbooks. In the present study, the last factor mentioned by the interviewees was the lack of time to search for information. As one of the interviewees puts it:

"Students seem to spend a lot of time on social media, but do not devote time to specialized TEFL courses".

\subsection{DISCUSSION}

The present study sought TEFL students' attitudes towards webquesting. It also sought the barriers to Webquesting behaviour. The findings of this study revealed that the students were not satisfied with their webquesting and that there were two major obstacles in their webquesting, namely, learners' constraints and teachers' constraints.

According to the findings of this study, learner-related factors influence students' information-seeking behavior in English language courses. These factors include behavioral and cognitive factors that are formed over time and can be rooted in the knowledge that a person has gained from his/her environment [23]. As teachers reported in interviews, students may avoid seeking information due to factors that stem solely from their psychological characteristics. Different researchers have pointed out some of these barriers in their research. For example, [26] noted students' inability to use non-Persian resources and lack of time. Another study [27] also mentioned weakness in English as the most important obstacle in students' information-seeking skills. Research [4] also considered lack of students' familiarity with related specialized databases as one of the obstacles. Similarly, research [5] also reported that lack of time is the most important barrier to information seeking for medical students. Consistent with these findings, the study [3] also pointed out the lack of time, unfamiliarity with foreign languages and lack of familiarity with academic sources among other factors.

The second category of barriers to information-seeking behavior were teacher-related barriers. Research [3] has also pointed to the lack of familiarity with the technology used in CALL and resources as barriers. Regarding lack of teachers' familiarity with different sources and their mere emphasis on the textbook, researchers [28] have pointed to the weakness of teachers' skills and their low awareness of information sources. Regarding the emphasis on the textbook, the present study is in line with the research [29]. All in all, teachers' role and the kind of environment they prepare for students' webquesting are very critical. It has been argued that "when teachers create WebQuests, they need to shift from creating prescriptive learning situations to developing environments that engage learners and require them to solve problems and construct knowledge that is most meaningful to them"[30, p. 47].

In sum, the findings can be interpreted in light of the argument that, as Riahi concluded in his study, the most important source of information for students is textbooks and the most important goal of searching for information is for doing homework. The importance of textbooks for students is the result of the pivotal role given to the textbooks by teachers and the final exams. Perhaps students' lack of interest in webquesting is partly due to such an undue emphasis. On the other hand, students' lack of interest can be due to the lack of 
attention and encouragement from the side of teachers to use the Internet resources. This is an issue that seems very important in the time of COVID-19.

\section{CONCLUSIONS AND PROSPECTS FOR FURTHER RESEARCH}

Since webquesting is necessary for English language students, it is very important to pay attention to the type of students' behavior in learning the courses of this field. In this regard, not paying attention to any individual, organizational and environmental factors may result in students' relying solely on textbooks and having no access to vast sources of information that help students learn communication skills. It seems necessary to pay special attention to the mentioned factors in order to make the best use of students' informationseeking behavior. In this regard, it is suggested that in-service teacher training courses provide teachers with the necessary training regarding information searching strategies and web resources in TEFL. At the same time TEFL teachers should in turn give necessary information as to the necessity of webquesting and arouse their interest in various available web sources.

This study, like any other study, faced limitations. The first limitation was the number of students who participated in the study. Future studies could recruit more participants from different universities in the country. The second limitation was that in the interview only students' perceptions were sought. Further studies can invite both students and teachers to the interview.

\section{REFERENCES (TRANSLATED AND TRANSLITERATED)}

[1] M. Nasiri, "The studying the behavior Behbahan Students and influence and the effect of teachers on their informing pattern," Journal of Academic Librarianship and Information Research, vol. 43, no. 39, pp. 153-181, 2005. (Persian)

[2] A. Riahi, "Information behaviors and information seeking of nursing students of Mazandaran University of Medical Science," The Journal of Medical Education and Development (JMED), vol. 12, no. 3, pp. 195-211, 2017. (Persian)

[3] A, Shar'atmadari, "A Qualitative Study on Stimulus and Barriers of Information-Seeking Behavior of Counselling MA Students," Quarterly Counseling Culture and Psychotherapy, vol. 4, no. 15, pp. 17-33, 2013. (Persian)

[4] A. Kalantari, A. Jowkar, H. Jahani Hashemi , "Information seeking behavior of postgraduate students of Qazvin University of medical sciences for retrieval of specialized images and videos," Payavard, vol. 11, no. 4, pp. 479-489, 2017. (Persian)

[5] J. Naeimi, S. Mohammad Esmaeil, “ The Assessment of information-seeking behavior of medical sciences University researchers of Khorasan Razavi using neural network approach," Library and Information Science Research (LISRJ), vol. 6, no. 2, pp. 80-96, 2017. (Persian)

[6] P. Memarbashi, N. Zamani Miandashti, "An Analysis of Information-Seeking Behavior Through The Internet Tmong Agricultural Undergraduate Students at Razi University of Kermanshah," Iranian Agricultural Extension and Education, vol. 9, no. 1, pp. 33-49, 2013. (Persian)

[7] F. Safari Rad, 'Investigation of information seeking behavior of postgraduate students of Shiraz University', Cultural Research Letter, vol. 7, no. 6, pp. 210-193, 2003. (in English)

[8] I. Redad, "Behavioral information seeking of postgraduate students of Islamic Azad University using World Wide Web," Journal of Library and Information Science, vol. 12, no. 3, pp. 141-168, 2009. (in English)

[9] M. Majidi, G. Shakerian, "The study of information seeking behavior of Allameh Tabataba'i university faculty members in using online resources," Journal management System, vol. 2, no. 6, pp. 105-126, 2016. (Persian)

[10] T. D. Wilson, "Human Information Behavior," Informing Science (Special Issue on Information Science Research), vol. 3, no. 2, pp. 49-55, 2000. (in English) 
[11] A. Adhami , "What is the information Seeking and Behavior of Information Seeking?," Iranian Research Institute for Information Science and Technology (IRANDOC), vol. 19, no. 3- 4, pp. 31-36, 2004. (Persian)

[12] S. Ebrahimy, Z F. Hekmat, A. Jowkar , "Prediction of information seeking behavior of Shiraz University graduate students based on the dimensions of goal orientations and creativity dimensions," Journal of Information Processing and Management, ; vol. 30, no. 4, pp. 965-996, 2015. (in English)

[13] A. Malliari, S. Korobili, Zapounidou, "Exploring the information seeking behavior of Greek graduate students: A case study set the University of Macedonia," The International Information \& Library Review, vol. 34, pp. 79-91, 2011. (in English)

[14] A. Norouzi Chakli, "The main and effective factors in information seeking behavior," Librarianship and Information, vol. 9, no. 1, pp. 144-175, 2006. (in English)

[15] M. Shohel, C. Mahruf, A. Kirkwood, "Using technology for enhancing teaching and learning in Bangladesh: challenges and consequences," Learning, Media and Technology, vol. 37, no. 4, pp. 414428, 2012. (in English)

[16] J. Lock, P. Redmond, "Embedded experts in online collaborative learning: A case study," The Internet and Higher Education, vol. 48, 2020. (in English)

[17] T. March , "What are WebQuests (really)?,” 2004. [Online]. Available: http://bestwebquests.com/whatç webquestsçare.asp (in English)

[18] R. Zheng, J. Perez, J. Williamson, J. Flygare, "WebQuests as perceived by teachers: Implications for online teaching and learning," Journal of Computer Assisted Learning, vol. 24, pp. 295-304, 2007. (in English)

[19] M. P. Murphy, “COVID-19 and emergency e-learning: Consequences of the securitization of higher education for post-pandemic pedagogy," Contemporary Security Policy,vol. 41, no. 3, pp. 1-14, 2020. (in English)

[20] P. Mayring, "Qualitative content analysis.” In: Flick, U., Kardoff, E. and Steinke, I. (eds.), A companion to qualitative research, London: Sage, pp. 266 - 269, 2000. (in English)

[21] J. W. Creswell, V. L. Plano Clark, Designing and conducting mixed methods research, Los Angeles, CA: Sage Publications,2011. (in English)

[22] H. Behroozfar, "Study of the resource-based teaching method in terms of achieving the goals of higher education and coordinating with the goals and services of academic libraries," Library and Information Science, vol. 16, no. 4, pp. 61-82, 2014 .(Persian)

[23] A. Norouzi Chakly, "The main and effective factors in the behavior of information seekers," Information and education, vol. 9, no. 33, pp. 174-143,2006. (Persian)

[24] R. Rahnavard, "The Impact of Internal and External Motivation on Knowledge Transfer (A Case Study: Higher Education and Research Management and Planning)," Human Resources Research, vol. 5, no. 18, pp. 31-48, 2015. (Persian)

[25] M. Bijani, H. Moradi, G. Karami , "Investigating the concept and place of motivation in adult educational programs," Work and Society, no. 133-132, pp. 100-112, 2011. (Persian)

[26] M. Bagh Jannati, N. Motamed, M. Bagh Jannati, A. Hamidi, "Inhibitive Factors of the Development and Growth of Critical Thinking in Libraries," Journal Studies in Library and Information Science, vol. 6 no. 13, pp. 25-50, 2014. (Persian)

[27] M. Amiramini khalafloo, P. Bayat, "Investigation of information seeking behavior of students of Bushehr Jahad Agriculture Training Center and providing solutions for its improvement," Agricultural Education Administration Research, vol. 10 no. 44, pp. 42-54, 2018. (Persian)

[28] H. Moghadaszadeh, "The study of information literacy of faculty members of Islamic Azad University, Mashhad Branch," Informatics and Informatics Monthly, Monthly , no. 8 , pp. 65-57, 2008.(Persian)

[29] A. Ramezanpour, S. Golshahi Rad ,"Evaluation of study pattern and the attitude of medical students and residents about study resources (books and notes) in Zanjan University of Medical Sciences - 20132014,” J Med Educ Dev, vol. 8, no. 19, pp. 41-52, 2015. (Persian)

[30] R. Zheng, B. Stucky, M. McMack, M. Menchana \& S. Stoddart, "WebQuest learning as perceived by higher-education learners." Tech Trends: Linking Research \& Practice to Improve Learning, 49(4), 4149,2005.(in English) 


\title{
ВЕБКВЕСТ НА КУРСАХ ТЕFL: ЯКІ ФАКТОРИ ВПЛИВАЮТЬ НА ІНФОРМАЦЙНО-ПОШУКОВУ ПОВЕДІНКУ СТУДЕНТІВ?
}

\author{
Маджид Фарахян \\ доцент кафедри прикладної лінгвістики \\ кафедра ELT, відділення Керманшаха, Ісламський університет Азад, Керманшах, Іран \\ ORCID ID 0000-0002-5367-5138 \\ farahian@iauksh.ac.ir

\section{Фаршад Пархамнія} \\ доцент кафедри знань та інформатики \\ департамент знань та інформатики, відділення Керманшаха, Ісламський університет Азад, Керманшах, \\ Iран \\ ORCID ID 0000-0003-1509-3329 \\ fparhamnia@yahoo.com

\section{Мілад Шейхбаної} \\ магістр прикладної лінгвістики \\ кафедра ELT, відділення Керманшаха, Ісламський університет Азад, Керманшах, Iран \\ ORCID ID 0000-0003-4971-6440 \\ miladsheikhbanooe@gmail.com
}

\begin{abstract}
Анотація. Збереження безперервності організаційних процесів залежить від використання інформації. Тому важливим є дослідження поведінки студентів під час пошуку інформації, зокрема студентів TEFL (Teaching English as a foreign language - Викладання англійської мови як іноземної), під час пандемії Covid-19. Оскільки на поведінку під час пошуку інформації можуть впливати різні фактори, ми прагнули вивчити ставлення студентів TEFL до вебквестування. При дослідженні перешкод, які супроводжували студентів TEFL під час вебквестування, були використані як якісний, так і кількісний підходи. Статистична сукупність становила 128 студентів TEFL, використано цілеспрямований метод вибірки. Результати дослідження показали, що студенти не були задоволені вебквестом, під час проведення якого визначилися дві основні перешкоди: обмежені можливості як учнів, так і вчителів. До факторів обмеження належали: незнання джерел в інтернеті, погані навички пошуку інформації, відсутність інтересу до деяких тем, відсутність навичок використання інтернету, погане знання англійської мови, відсутність у вчителів підготовки до CALL (Computer assisted language learning - вивчення мови за допомогою комп'ютера), відсутність допомоги з боку вчителів, небажання вчителів використовувати, крім підручників, інші ресурси, а також відсутність у студентів мотивації та часу. Отримані дані мають значення для вчителів TEFL, оскільки, судячи 3 якісних даних, найважливішим джерелом інформації учнів є підручники, а найважливішою метою пошуку інформації виконання домашніх завдань. Важливість підручників для учнів пояснюється тією ключовою роллю, яку вчителі надають підручникам та випускним іспитам. Можливо, саме такий підхід впливає на відсутність інтересу студентів до вебквестів. 3 іншого боку, відсутність інтересу студентів до вебквестів була пов'язана 3 відсутністю уваги та заохочення 3 боку вчителів до використання ресурсів інтернету.
\end{abstract}

Ключові слова: вебквест; перешкоди під час пошуку інформації; студенти TEFL.

\section{ВЕБ-КВЕСТ НА КУРСАХ ТЕЕL: КАКИЕ ФАКТОРЫ ВЛИЯЮТ НА ИНФОРМАЦИОННО-ПОИСКОВОЕ ПОВЕДЕНИЕ УЧАЩИХСЯ?}

\author{
Маджид Фарахян \\ доцент кафедры прикладной лингвистики \\ кафедра ELT, отделение Керманшаха, Исламский университет Азад, Керманшах, Иран \\ ORCID ID 0000-0002-5367-5138 \\ farahian@iauksh.ac.ir
}




\title{
Фаршад Пархамния
}

доцент кафедры знаний и информатики

департамент знаний и информатики, отделение Керманшаха, Исламский университет Азад, Керманшах, Иран

ORCID ID 0000-0003-1509-3329

fparhamnia@yahoo.com

\section{Милад Шейхбаной}

магистр прикладной лингвистики

кафедра ELT, отделение Керманшаха, Исламский университет Азад, Керманшах, Иран

ORCID ID 0000-0003-4971-6440

miladsheikhbanooe@gmail.com

\begin{abstract}
Аннотация. Сохранение непрерывности организационных процессов зависят от использования информации. Поэтому представляется важным исследование поведения студентов во время поиска информации, в частности студентов TEFL (Teaching English as a foreign language - Преподавание английского языка как иностранного), во время пандемии Covid-19. Поскольку на поведение во время поиска информации могут влиять различные факторы, мы стремились изучить отношение студентов TEFL к веб-квестированию. Были исследованы препятствия (преграды), которые сопровождали студентов TEFL во время вебквестирования, использован как качественный, так и количественный подходы. Статистическая совокупность составляла 128 студентов TEFL, использован целенапрвленный метод выборки. Результаты исследования показали, что студенты не были удовлетворены веб-квестом, во время проведения которого определились два основных препятствия: ограниченные возможности как учащихся, так и учителей. К факторам ограничения относились: незнание источников в Интернете, плохие навыки поиска информации, отсутствие интереса к некоторым темам, отсутствие навыков использования Интернета, плохое знание английского языка, отсутствие у учителей подготовки к CALL (Computer assisted language learning - изучение языка с помощью компьютера), отсутствие помощи со стороны учителей, невнимательность учителей к ресурсам, не относящимся к учебникам, а также отсутствие у студентов мотивации и времени. Полученные данные имеют значение для учителей TEFL, поскольку, судя по качественным данным, наиболее важным источником информации для учащихся являются учебники, а наиболее важной целью поиска информации является выполнение домашних заданий. Важность учебников для учащихся объясняется той ключевой ролью, которую учителя придают учебникам и выпускным экзаменам. Возможно, именно такой подход влияет на отсутствие интереса студентов к веб-квестам. С другой стороны, отсутствие интереса студентов к веб-квестам было также связано с отсутствием внимания и поощрения со стороны учителей к использованию ресурсов Интернета.
\end{abstract}

Ключевые слова: веб-квест; препятствия на пути поиска информации; студенты TEFL.

\section{$(c c)$ BY-NC-SA}

ThisworkislicensedunderCreativeCommonsAttribution-NonCommercial-ShareAlike 4.0 InternationalLicense. 